the teenagers cognitive tasks decision accompanied by a large psycho-emotional stress of the body, and the predominance of compensatory distress level of sympathetic regulation of cardiac activity.

Key words: heart rate variability, distress, vagotonia, sympathicotonia.

Стаття надійшла до редколегії 24.11.2015 p.

УдК 57.047:616.018[612.32]

\author{
Валентина Луженецька, \\ Галина Кузнєцова, \\ Ганна Світіна, \\ Людмила Гарманчук, \\ Володимир Шаблій, \\ Володимир Рибальченко
}

\title{
Вплив плацентарних клітин мезенхімального походження на слизову оболонку шлунка щурів
}

Досліджено вплив плацентарних мезенхімальних клітин алогенного та ксеногенного походження на слизову оболонку фундального відділу шлунка щурів. Показано, що мезенхімальні стовбурові клітини щурів і людини мають негативний вплив на слизову оболонку шлунка, що прямо пропорційний кількості уведення клітин.

Ключові слова: клітинна терапія, мезенхімальні стовбурові клітини, стовбурові клітини щурів, стовбурові клітини людини, слизова оболонка шлунка.

Постановка наукової проблеми та її значення. Клітинна терапія - сучасний метод лікування захворювань, що потребують масивного відновлення тканин, в основі якого лежить трансплантація від донора до реціпієнта стовбурових і прогеніторних клітин (алотрансплантація) або власних клітин (аутотрансплантація). Стовбурові клітини (СК) успішно використовують у терапії опіків та ран, гострого інфаркту міокарда, для відновлення кровотворної активності червоного кістового мозку після хіміотерапії чи при імунодефіцитах [1]. Наявні відомості про застосування СК у терапії нейродегенеративних [2] й аутоімунологічних захворювань [3].

Найбільш перспективними в плані клінічного застосування виявилися мезенхімальні стовбурові клітини (МСК) - плюрипотентні стовбурові клітини дорослого організму, що забезпечують відновлення тканин хазяїна, здатні диференціюватися в напрямі низки соматичних клітин [4]. У ролі джерел МСК використовують червоний кістковий мозок, пуповинну кров та плаценту, жирову тканину, слизову оболону носоглотки.

При захворюваннях і пошкодженнях МСК задіяні в процесах тканинної регенерації, а також беруть участь у регуляції імунної відповіді [5]. При репарації МСК мігрують у ділянку пошкодження, «приваблені» цитокінами запалення. МСК також мають здатність до хоумінгу - міграції в ділянку своєї «стовбурової ніші». Органи, у яких переважно накопичуються МСК при внутрішньовенному уведенні, - це червоний кістковий мозок, селезінка, легені, печінка, слизова оболонка шлунка [12], а також пухлинні вузли. Тому широке застосування МСК у медичній практиці неможливе без грунтовного вивчення їх онкогенного потенціалу. Так, МСК можуть бути джерелом пухлино-асоційованих фібробластів, які $є$ важливими компонентами строми пухлини й активаторами пухлинного росту [6]. За даними інших науковців [7], МСК активно мігрують до первинної пухлини або метастатичного вузла, де, впливачи на мікооточення пухлини, пригнічують іiі ріст. У дослідженнях in vitro при співкультивуванні пухлинних клітин та МСК показано різноспрямований вплив останніх на проліферацію й виживання пухлинних клітин залежно від їх природи та умов культивування [17]. Наведені дані свідчать про неоднозначність ефектів МСК і важливість грунтовного вивчення їхньої поведінки в організмі за умов норми й різних патологічних станів. При цьому особливу увагу варто звернути на органи - мішені МСК.

\footnotetext{
(С Луженецька В., Кузнєцова Г., Світіна Г., Гарманчук Л., Шаблій В., Рибальченко В., 2015
} 
Мета роботи - дослідження впливу плацентарних МСК алогенного та ксеногенного походження на слизову оболонку фундального відділу шлунка здорових щурів.

Матеріали та методи дослідження. Дослідження на щурах проведено відповідно до принципів біоетики, законодавчих норм і положень «Європейської конвенції про захист хребетних тварин, що використовуються для дослідних та наукових цілей» (Страсбург,1986) i «Загальних етичних принципів експериментів на тваринах», ухвалених Першим національним конгресом із біоетики (Київ, 2001).

Дослідження проводили на 40 статевозрілих нелінійних білих щурах-самцях із початковою масою тіла 220-230 г. Щурів утримували в умовах віварію на стандартному харчовому раціоні за природного освітлення. Експеримент тривав п'ять тижнів. Плацентарні клітини щурів (ПКЩ), отримані в білих безпородних самок на 21-шу добу вагітності та культивовані протягом чотирьох пасажів за стандартних умов, уводили у хвостову вену в кількості 0,5 і $2,0 * 10^{6}$ клітин/щура у 0,5 мл фізіологічного розчину. Плацентарні клітини людини (ПКЛ), отримані з плацент від нормальних пологів та культивовані так само, уводили у хвостову вену у кількості $2,0 * 10^{6}$ клітин/щура в 0,5 мл фізіологічного розчину. Контрольним тваринам уводили 0,5 мл фізіологічного розчину у хвостову вену. Сформовано чотири групи: контроль (I), ПКЩ $0,5^{*} 10^{6}$ клітин/щура (II), ПКЩ $2 * 10^{6}$ клітин/щура (III), ПКЛ $2 * 10^{6}$ клітин/щура (IV).

Плацентарні клітини щурів та людини охарактеризовано як стовбурові клітини мезенхімального походження та надано Інститутом клітинної терапії.

Через п’ять тижнів тварин знеживлювали через асфіксію $\mathrm{CO}_{2}$ і наступну дислокацію шийних хребців. Для гістологічного дослідження виділяли фундальну частину шлунка, промивали у фізіологічному розчині та фіксували в суміші Буена протягом 14 діб. Після стандартної гістологічної обробки фрагменти шлунка заливали в парафін, виготовляли зрізи товщиною 5-7мкм, які забарвлювали гематоксиліном Бемера з дофарбуванням еозином й оранжем G [8].

Стан слизової оболонки шлунка оцінювали, грунтуючись на візуальному аналізі препаратів і на морфометричних вимірах, які проводили за допомогою світлового мікроскопа Axioskop 40 iз фотокамерою Axio Cam MRc5 (Karl Zeiss) та програми WCIF Image J. Вимірювали товщину слизової оболонки, глибину шлункових ямок, довжину залоз, площу парієтальних клітин та їхніх ядер, площу головних клітин і їхніх ядер [9]. Математичну обробку даних проводили за допомогою програм статистичного пакета аналізу даних Microsoft Excel для персонального комп`ютера з використанням критерію Стьюдента [10].

Виклад основного матеріалу й обгрунтування отриманих результатів дослідження. Слизова оболонка шлунка щурів контрольної групи має типову для цього виду тварин будову (рис. 1а) без ознак патологічних процесів (товщина слизової в межах фрагмента однакової товщини, зони головних і парієтальних клітин чітко візуалізовані, залози розміщені компактно, клітинний склад і співвідношення головні: парієтальні клітини - у межах гістологічної норми) (табл. 1).

Таблиия 1

Стан слизової оболонки шлунка щурів за уведення ПКЩ $0,5 * 10^{6}$ клітин/щура, ПкЩ $2 * 10^{6}$ клітин/щура та ПКЛ $2 * 10^{6}$ клітин/щура $(M \pm m)$

\begin{tabular}{|c|c|c|c|c|}
\hline Стан слизової оболонки & Контроль & $\begin{array}{l}\text { Пкщ } 0,5 * 10^{6} \\
\text { клітин/щура }\end{array}$ & $\begin{array}{l}\text { Пкщ } 2 * 10^{6} \\
\text { клітин/щура }\end{array}$ & $\begin{array}{c}\text { ПКЛ } \\
2^{* 10^{6}} \\
\text { клітин/щура }\end{array}$ \\
\hline Товщина слизової оболонки, $\mu \kappa M^{2}$ & $523,7 \pm 14,3$ & $523,1 \pm 15,1$ & $514,2 \pm 13,3$ & $527,6 \pm 9,6$ \\
\hline Глибина шлункових ямок, $M \kappa M^{2}$ & $56,2 \pm 5,4$ & $55,4 \pm 5,2$ & $52,3 \pm 4,8^{*}$ & $56,4 \pm 2$ \\
\hline Довжина шлункових залоз, $м \kappa м^{2}$ & $423,1 \pm 8,5$ & $421,9 \pm 7,7$ & $402 \pm 7,2$ & $412,8 \pm 5,6$ \\
\hline Площа парієтальних клітин, $\boldsymbol{м k M ^ { 2 }}$ & $117,5 \pm 7,9$ & $117,9 \pm 8,4$ & $127 \pm 6,3^{*}$ & $127,4 \pm 4,8^{*}$ \\
\hline $\begin{array}{l}\text { Площа ядер парієтальних клітин, } \\
\text { мкм }\end{array}$ & ,9 & $18,4 \pm 2,2$ & $15,6 \pm 0,9 *$ & $19,9 \pm 1,3^{*}$ \\
\hline Площа головних клітин, $м \kappa м^{2}$ & $56,7 \pm 5,3$ & $55,2 \pm 5,6$ & $51,8 \pm 4 *$ & $54,2 \pm 2$ \\
\hline Площа ядер головних клітин, $м \kappa м^{2}$ & $11,6 \pm 1,3$ & $11,3 \pm 1,5$ & $10,6 \pm 0,8^{*}$ & $12,3 \pm 0,3 *$ \\
\hline
\end{tabular}

Примітки. *p $\leq 0,05$ порівняно з контролем.

У тварин, що отримували ПКЩ $0,5 * 10^{6}$ клітин/щура, у стінці шлунка відзначено незначний набряк підслизової основи, подекуди трапляється вогнищева поверхова десквамація поверхневих 
епітеліальних клітин та незначна інфільтрація слизової еозинофілами (рис. 1б). Значення морфометричних показників не відрізняються від контрольних.

У тварин, що отримували ПКЩ $2 * 10^{6}$ клітин/щура, простежено помірне повнокрів'я судин підслизової основи слизової оболонки шлунка, ï вогнищеву помірну інфільтрацію лімфоцитами та еозинофілами (рис.1в), вогнищеву десквамацію поверхового епітелію. Порівняно з контролем, вірогідно зменшується глибина шлункових ямок (на 6,9 \%), площа головних клітин і їхніх ядер (відповідно, на 8,6 \% і 9 \%), площа ядер парієтальних клітин (на $14 \%$ ); при цьому площа парієтальних клітин збільшується (на $8 \%$ ).

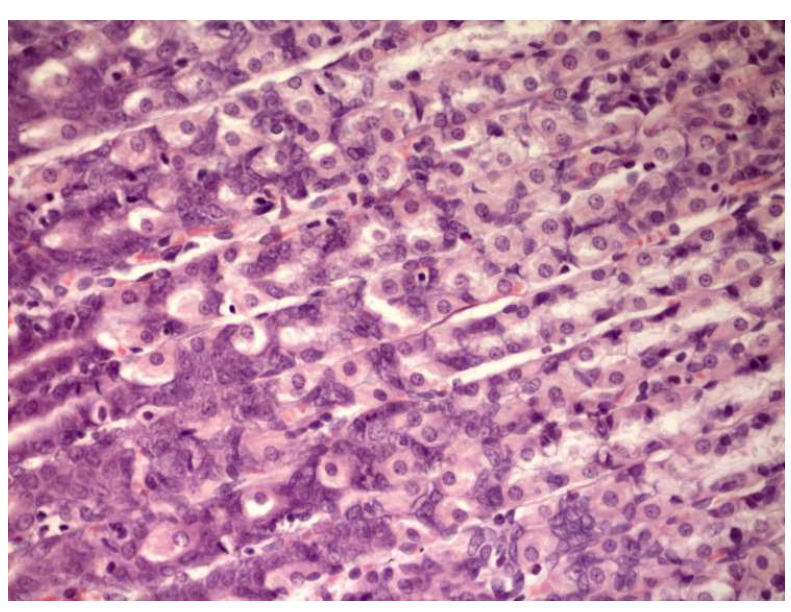

a

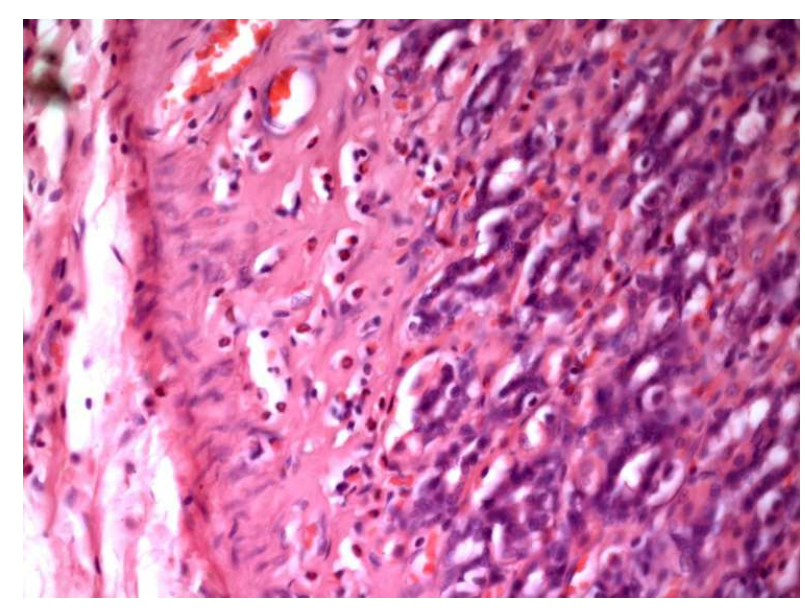

B

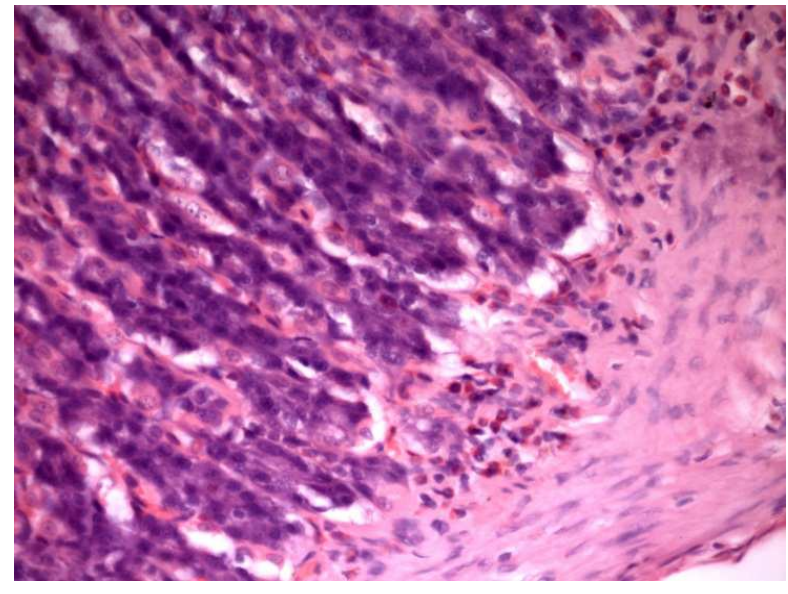

б

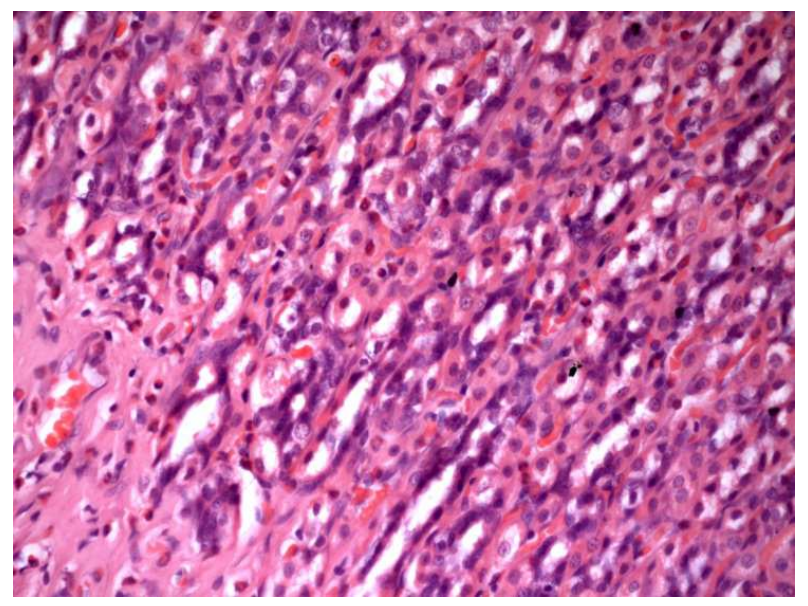

$\Gamma$

Рис. 1. Мікрофотографія слизової оболонки фундальної частини шлунка щурів груп контролю (а), ПКЩ $0,5 * 10^{6}$ клітин/щура (б), ПКЩ $2 * 10^{6}$ клітин/щура (в), ПКЛ $2 * 10^{6}$ клітин/цура (2). Забарвлення гематоксилінеозин-оранж, $x 400$.

У тварин групи ПКЛ $2 * 10^{6}$ клітин/щура зміни слизової оболонки шлунка подібні до змін, що спостерігаються в попередній групі, проте дещо більш виражені: помітний помірний набряк підслизової оболонки, помірне повнокрів'я окремих судин, поширена інфільтрація слизової лімфоцитами та еозинофілами (рис. 1г), місцями десквамація поверхових шарів епітелію. Порівняно з контролем, вірогідно зростають площа парієтальних клітин і їхніх ядер (відповідно, на 8,4 \% та 9,7 \%) і площа ядер головних клітин (на 5,6\%).

Отже, трансплантація плацентарних клітин мезенхімального походження здоровим щурам викликає запальні зміни в слизовій оболонці шлунка: набряк, підвищене повнокрів'я судин, інфільтрацію лімфоцитами та еозинофілами. При цьому за умов уведення меншої кількості клітин зміни значно менш виражені, порівняно з уведенням більшої кількості алогенних клітин та клітин людини. 
Запальні процеси можна пояснити імунними реакціями відторгнення трансплантата, оскільки ПКЩ і ПКЛ несуть на собі певний набір антигенів, чужорідних для організму донора, що має повноцінну імунну систему [11]. Інтенсивніша реакція на ПКЛ може обумовлюватися більшою імунологічною «чужорідністю» клітин людини, порівняно з клітинами тварини цього ж виду. Крім того, імовірно, плацентарні клітини самі здатні індукувати запальну відповідь у слизовій оболонці. Відомо, що МСК плацентарного походження при трансплантації в організм здатні накопичуватися, окрім легенів, червоного кісткового мозку та селезінки, також у печінці й слизовій оболонці шлунка, де детектуються в достатній кількості принаймні протягом 30 діб [12]. Відомо також, що здатність трансплантованих МСК стимулювати регенерацію уражених органів, зокрема печінки, зумовлена і продукцією цими клітинами IL-6 [13], який також $є$ прозапальним цитокіном. При зв’ язуванні IL-6 із відповідним рецептором простежується димеризація рецепторів через субодиниці gр130 й активується сигнальний шлях Jak/STAT. Jak/STAT - один 3 основних сигнальних шляхів рецепторів ростових факторів, що зумовлює стимуляцію проліферації, виживання клітини та ії захист від апоптозу. Крім того, стимуляція Jak/STAT має прозапальний ефект. Показано, що за умов трансплантації MCK експресія IL-6 в органі-мішені зростає й зберігається підвищеною протягом тривалого часу [14]. Тому ми припускаємо, що ПКЩ і ПКЛ накопичуються в слизовій оболонці шлунка та провокують запальні реакції як чужорідні для імунної системи хазяїна об'єкти, а також, імовірно, унаслідок гіперпродукції ними IL-6 i симуляції Jak/STAT сигнального шляху в клітинах строми слизової оболонки.

Збільшення площі перетину парієтальних клітин та їхніх ядер за умов уведення ПКЩ і ПКЛ у великій кількості може свідчити про посилення секреції соляної кислоти у шлунку [15]. Відомо, що одним зі стимуляторів секреції соляної кислоти є гістамін, що продукується ентерохромафіноподібними (ECL) клітинами [16]. Проте гістамін також може вивільнятися базофілами й тучними клітинами, яких багато в слизовій оболонці шлунка, при алергічних та імунних реакціях. Імовірно, унаслідок запального процесу кількість гістаміну в слизовій оболонці шлунка зростає, що стимулює посилення секреції соляної кислоти парієнтальними клітинами.

Зменшення площі перетину головних клітин і їхніх ядер за уведення ПКЩ у високій дозі та зростання значень цих показників за уведення ПКЛ може свідчити про пригнічення функціональної активності головних клітин і, відповідно, іiі посилення. Відомо, що секреція пепсиногена - основного компонента секрету головних клітин, пов'язана із секрецією соляної кислоти. Показано, що секреція головних клітин може стимулюватися через місцевий холінергічний рефлекс унаслідок зниження $\mathrm{pH}$ шлункового вмісту та безпосередньо гістаміном [16]. При цьому у високих дозах гістамін гальмує секрецію головних клітин. Стимулятором секреції головних клітин $є$ також простагландин Е2 - один із медіаторів запалення [11]. Тому, імовірно, різна реакція головних клітин на уведення ПКЩ і ПКЛ може бути зумовлена відмінностями в секреції соляної кислоти парієтальними клітинами й різним умістом гістаміну та/або простагландину Е2 у шлунковому секреті.

Висновки й перспективи подальших досліджень. ПКЩ при уведенні в кількості $0,5 * 10^{6}$ клітин/щура змін функціонального стану слизової оболонки шлунка не викликають, при уведенні в кількості $2 * 10^{6}$ клітин/щура сприяють появі ознак посилення секреції парієтальних клітин та пригнічення секреції головних клітин.

ПКЛ при введенні в кількості $2 * 10^{6}$ клітин/щура сприяють появі ознак посилення секреції як парієтальних, так і головних клітин.

ПКЩ і ПКЛ при введенні здоровим щурам із повноцінною імунною системою спричиняють розвиток запалення в слизовій оболонці шлунка, інтенсивність якого пропорційна кількості уведених клітин.

\section{Джерела та література}

1. Репин В. С. Эмбриональные стволовые клетки: фундаментальная биология и медицина / В. С. Репин, А. А. Ржанинова, Д. А. Шаменков. - М. : Мед, 2002. - 96 с.

2. Liu S. Embryonic stem cells differentiate into oligodendrocytes and myelinate in culture and after spinal cord transplantation / S. Liu, Y. Qu, T. J. Stewart [et al.] // Proc.Natl. Acad. Sci US. - 2000. - V. 97. - P. 6126-31.

3. Кругляков П. В. Мезенхимальные стволовые клетки и иммунопатологические состояния организма / П. В. Кругляков, Е. А. Лохматова // Клеточная трансплантология и тканевая инженерия. - 2006. - № 3. C. $83-87$. 
4. Chamberlain G. Concise Review: Mesenchymal Stem Cells: Their Phenotype, Differentiation Capacity, Immunological Features, and Potential for Homing / G. Chamberlain // Stem. Cells. - 2007. - Vol. 25, № 11. P. 2739-2749.

5. Jing D. Hematopoietic stem cells in co-culture with mesenchymal stromal cells--modeling the niche compartments in vitro / D. Jing, A. V. Fonseca, N. Alakel [et al.] // Haematologica. - 2010. - V. 95, № 4. P. 542-50.

6. Kucerova L. Tumor-driven Molecular Changes in Human Mesenchymal Stromal Cells / L. Kucerova, J. Zmajkovic, L. Toro [et al.] // Cancer Microenviron. - 201. - V. 8, № 1. - P.1-14.

7. Ahn J.O. Human adipose tissue-derived mesenchymal stem cells inhibit melanoma growth in vitro and in vivo / J. O. Ahn, Y. R. Coh, H. W. Lee [et al.] // Anticancer Res. - 2015. - V. 35, № 1. - P. 159-68.

8. Горальський Л. П. Основи гістологічної техніки і морфофункціональні методи досліджень у нормі та при патології / Л. П. Горальський, В. Т. Хомич, О. І. Кононський. - Житомир : Полісся, 2005. - 288 с.

9. Автандилов Г. Г. Медицинская морфометрия / Г. Г. Автандилов - М. : Медицина, 1990. - 384 с.

10. Лопач С. Н. Статистические методы в медико-биологических исследованиях с использованием Ехеl / С. Н. Лопач, А. В. Чубенко, П. Н. Бабич. - К. : Морион, 2001. - 410 с.

11. Коико Р. Иммунология / Р. Коико, Д. Саншайн, Э. Бенджамини / пер. с англ. А. В. Камаева, А. Ю. Кузнецовой ; под ред. Н. Б. Серебряной. - М. : Издат. центр «Академия», 2008. - 368 с.

12. Wu C. G. In vivo tracking of human placenta derived mesenchymal stem cells in nude mice via $14 \mathrm{C}-\mathrm{TdR}$ labeling / C. G. Wu, J. C. Zhang, C. Q. Xie [et al.] // BMC Biotechnol. - 2015. - V.15. - № 55.

13. Jung J. Epigenetic Alterations of IL-6/STAT3 Signaling by Placental Stem Cells Promote Hepatic Regeneration in a Rat Model with CCl4-induced Liver Injury / J. Jung, J. W. Moon, J. H. Choi [et al.] // Int J Stem Cells. - 2015. - V. 8, №1. - P. 79-89.

14. Kim M. K. Secretory factors of human chorion-derived stem cells enhance activation of human fibroblasts / M. K. Kim, B. F. Seo, K. J. Kim [et al.] // Cytotherapy. - 2015. - V.17, № 3. - P. 301-309.

15. Парфенов А. И. Энтерология / А. И. Парфенов. - М. : Триада-Х, 2002. - 744 с.

16. Коротько Г. Ф. Физиология системы пищеварения / Г. Ф. Коротько. - Краснодар : [б. и.], 2009. - 608 с.

17. Колесник Д. Л. Взаємодія ендотеліальних та пухлинних клітин за умов їхнього «контактного» та «безконтактного» співкультивування / Д. Л. Колесник, Л. В. Гарманчук, О. М. Пясковська, Г. І. Соляник // Доп. НАН України. - 2009. - № 10. - С. 167-171.

Луженецкая Валентина, Кузнецова Галина, Свитина Анна, Гарманчук Людмила, Шаблий Владимир, Рыбальченко Владимир. Влияние плацентарных клеток мезенхимального происхождения на слизистую оболочку желудка крыс. Установлено, что трансплантация плацентарных клеток (ПК) мезенхимального происхождения здоровым крысам вызывает воспалительные изменения в слизистой оболочке желудка: отек, полнокровие сосудов, инфильтрацию лимфоцитами и эозинофилами. При этом при условии введения меньшего количества ПК крыс $\left(0,5^{*} 10^{6}\right.$ клеток/крысу) структурных и функциональных изменений слизистой оболочки не обнаружено, тогда как ПК крыс при введении в максимальном исследованном количестве вызывают усиление секреции париетальных клеток и угнетение секреции главных клеток. ПК человека в количестве $2 * 106$ клеток/крысу способствуют возникновению признаков воспаления и усиления секреции как париетальных, так и главных клеток.

Ключевые слова: клеточная терапия, мезенхимальные стволовые клетки, стволовые клетки крыс, стволовые клетки человека, слизистая оболочка желудка.

Luzhenetska Valentyna, Kuznietsova Halyna, Svitina Anna, Harmanchuk Ludmyla, Shablii Volodumyr, Rybalchenko Volodumyr. Influence of Placenta Derived Cells of Mesenchymal Origin on Rat Gastric Mucosa. It is established that transplantation of placenta derived cells (PC) of mesenchymal origin to healthy rats causes inflammatory changes in the gastric mucosa manifested by edema, vascular congestion, lymphocytic and eosinophilic infiltration. No structural and functional changes of gastric mucosa caused by introduction of fewer PCs amount $\left(0.5^{*} 10^{6}\right.$ cells per rat) were observed, whereas maximal investigated rat RC amount causes increase of secretion of the parietal cells and inhibition of the secretion of the main cells. Human PC when transplanted in amount of $2 * 10^{6}$ cells per rat promotes occurrence the attributes of parietal and main cells enhanced secretion.

Key words: cell therapy, mezenhymal stem cells, rat stem cells, human stem cells, gastric mucosa.

Стаття надійшла до редколегії 28.09.2015 p. 